\title{
Pengembangan Perangkat Pembelajaran Menggunakan Model Problem Posing Model Berorientasi Kemampuan Pemecahan Masalah Matematis
}

\author{
Resyania Aprilla Putri' ${ }^{1)}$, Endang Istikomah ${ }^{2)}$, Aulia Sthephani ${ }^{3)}$, Zetriuslita $^{4)}$ \\ ${ }^{1}$ Prodi Pendidikan Matematika Universitas Islam Riau \\ email: ${ }^{1}$ resyaniaaprilla@student.uir.ac.id \\ 2endangistikomah@edu.uir.ac.id \\ 3auliasthephani@gmail.com \\ 4zetriuslita@edu.uir.ac.id
}

\begin{abstract}
Abstrak
Penelitian ini bertujuan untuk mendeskripsikan tingkat kevalidan perangkat pembelajaran matematika dengan menggunakan model Problem Posing berorientasi kemampuan pemecahan masalah matematis pada materi statistika yang teruji valid. Model pengembangan pada penelitian ini menggunakan model Plomp yang mempunyai tiga tahap yaitu Fase Pendahuluan (Preliminary research), Fase Pembuatan Prototype (Prototype Phase), Fase Penilaian (Assessment Phase). Teknik pengumpulan data yang digunakan adalah validasi perangkat pembelajaran. Instrumen pengumpulan data yang digunakan adalah lembar validasi. Teknik analisis data yang dilakukan yaitu teknik analisis statistik deskriptif. Hasil analisis validasi penelitian oleh tiga validator diperoleh rata-rata validasi per-RPP dari setiap validator sebesar $100 \%$ untuk aspek indikator satu yang diukur dengan skala Guttman yang mana kriteria sangat valid dan $80,36 \%$ untuk aspek dua sampai tujuh yang diukur dengan skala Likert yang mana kriteria valid, dan untuk rata-rata validasi per-LKPD dari setiap validator sebesar 93,33\% untuk aspek satu yang diukur dengan skala Guttman yang mana kriteria sangat valid dan $75 \%$ untuk aspek dua sampai tiga yang diukur dengan skala Likert yang mana kriteria valid. Berdasarkan hasil penelitian tersebut dapat disimpulkan bahwa pengembangan perangkat pembelajaran menggunakan model Problem posing berorientasi kemampuan pemecahan masalah matematis telah teruji kevalidannya.
\end{abstract}

Kata kunci : LKPD, RPP, Problem Posing

\begin{abstract}
This study aims to describe the level of validity of mathematics learning tools using the Problem Posing model oriented to mathematical problem solving abilities on statistics which has been tested valid. The development model in this study uses the Plomp model which has three stage, namely the Preliminary Research Phase, the Prototype Phase, the Assessment Phase. The data collection techniques used were the validation of learning tools. The data collection instrument used was a validation sheet. The data analysis technique used is descriptive statiscal analysis technique. The result of the research validation analysis by three validators obtained an average validation every RPP of each validator was $100 \%$ for aspect of indicator one as measured by guttman scale of which are very valid criteria and 80,36\% for aspect of indicator two to seven as measured by likert scale of which are valid criteria, and for the average validation every LKPD of each validator was 93,33\% for aspect of indicator one as measured by guttman scale of which are very valid criteria and $75 \%$ aspect of indicator two to three as measured by likert scale of which are valid criteria. Based on the results of this study it can be concluded that the development of learning tools using the Problem Posing model oriented to the mathematical problem solving abilities has been tested for its validity.
\end{abstract}

Keywords: $L K P D, R P P$, Problem Posing 
Pengembangan Perangkat Pembelajaran Menggunakan Model Problem Posing Berorientasi Kemampuan Pemecahan Masalah Matematis

Resyania Aprilla Putri ${ }^{1)}$, Endang Istikomah ${ }^{2)}$

\section{PENDAHULUAN}

Matematika adalah ilmu yang manfaatnya dapat dirasakan dalam kehidupan sehari-hari. Ini dapat dirasakan dari hal yang mendasar hingga ke hal yang paling rumit sekalipun. Walaupun masih banyak orang yang tidak menyukai matematika tetapi pada dasarnya matematika merupakan ilmu yang menjadi dasar dalam kehidupan (Yolanda \& Wahyuni, 2020: 170). Di Indonesia pembelajaran matematika sudah diajarkan sejak pendidikan dasar hingga ke Perguruan Tinggi (Jamal, 2018: 41). Ini dikarenakan matematika merupakan ilmu yang bersifat universal yang menjadi dasar dalam pengembangan teknologi-teknologi modern dan memiliki peran penting dalam berbagai disiplin ilmu yang dapat memajukan cara berpikir manusia sehingga diperlukan pembelajaran yang dilakukan secara terus menerus. Menurut Zetriuslita dan Wirmaningsih (2013: 103) guru juga memliki peran untuk membuat proses pembelajaran yang menarik, ini dikarenakan dapat meningkatkan partisipasi peserta didik untuk aktif dalam belajar. Beberapa cara yang dapat dilakukan guru untuk menciptakan pembelajaran yang menarik adalah membuat kegiatan pembelajaran yang meningkatkan pengetahuan untuk bekerja dan bertanggung jawab, mendorong peserta didik untuk membangun pengetahuannya sendiri serta melakukan kegiatan diskusi untuk melatih komunikasi dan interaksi antar peserta didik. Keberhasilan dalam pembelajaran matematika dapa tdilihat dari tingkat pemahaman, pengetahuan dan prestasi belajar yang dimiliki oleh peserta didik.

Pada saat melakukan observasi di MTs Dar El Hikmah Pekanbaru pada hari Senin tanggal 19 Oktober 2020, kendala yang ditemukan dalam pembelajaran matematika juga dikarenakan guru dalam mengajar hanya menggunakan sebuah buku sebagai satu-satunya sumber bahan ajar. Perangkat pembelajaran pertama yang menjadi kendala di dalam proses pembelajaran adalah Rencana Pelaksanaan Pembelajaran (RPP). Rencana pelaksanaan pembelajaran (RPP) adalah rencana yang menjelaskan tata cara dan pelaksanaan pembelajaran untuk mencapai satu kompetensi dasar yang ditetapkan dalam standar isi yang dipaparkan dalam silabus (Trianto, 2012: 108). Seorang guru harus berupaya untuk menyusun sendiri perangkat pembelajaran yang sesuai dengan keadaan serta kebutuhan peserta didik sebelum proses pembelajaran di dalam kelas dimulai. Selanjutnya, saat melakukan observasi dilaksanakan pada hari dan tanggal yang sama juga, didapatkan informasi bahwa Pembelajaran matematika yang berlangsung di MTs Dar El Hikmah Pekanbaru, juga belum menggunakan LKPD. Hal ini akan menjadi kelemahan peserta didik dalam kemampuan pemecahan masalah matematika dalam aspek merencanakan penyelesaian dan memeriksa kembali ini disebabkan oleh proses pembelajaran yang berlangsung cenderung berpusat pada guru dan ketika dalam belajar guru belum memberikan masalah-masalah yang berhubungan dengan kemampuan pemecahan masalah. Di mana kemampuan pemecahan masalah peserta didik hanya sebatas dari contoh soal yang diberikan oleh guru. Dengan menggunakan LKPD akan memberikan kesempatan kepada peserta didik untuk meningkatkan kemampuan langkah-langkah pemecahan masalah matematis yang dimilikinya.

Berdasarkan dari kelemahan-kelemahan yang telah disebutkan di atas, maka dapat dilihat pentingnya penggunaan pengembangan perangkat pembelajaran matematika. Dalam penelitian ini selain RPP perangkat pembelajaran yang juga dikembangkan adalah LKPD. Hamdani (2011: 74) menjelaskan bahwa LKPD adalah kumpulan dari informasi-informasi maupun soalsoal yang digunakan untuk meningkatkan keterlibatan peserta didik dalam belajar yang berguna sebagai sarana pendukung RPP. Hal ini dikarenakan LKPD merupakan salah satu perangkat pembelajaran yang dapat digunakan oleh guru maupun peserta didik di dalam kelas secara bersamaan dengan sumber belajar atau perangkat pembelajaran yang lain (Widjajanti, 
2008:1). Selain dari perangkat pembelajaran yang berkualitas baik, diharapkan suatu pembelajaran matematika juga menerapkan suatu model yang dapat mengubah proses pembelajaran dari kondisi yang mana guru mengajar (teacher center) menjadi kondisi peserta didik yang belajar (student center) atau melibatkan peserta didik secara aktif dalam proses pembelajaran. Menurut Pertiwi dan Istikomah (2020: 52) pembelajaran matematika sangat cocok untuk menggunakan sistem berkelompok, ini dikarenakan materi yang ada dalam matematika tidak cukup hanya mengetahui dan menghafal konsep-konsep yang ada melainkan juga memerlukan pemahaman serta kemampuan untuk menyelesaikan permasalahan dengan baik dan benar?

Model pembelajaran yang diprediksi mampu mengubah proses pembelajaran tersebut adalah pembelajaran matematika dengan menggunakan model pembelajaran problem posing. Shoimin (2014: 133) menyatakan bahwa problem posing merupakan model pembelajaran yang menuntut peserta didik menyusun pertanyaan sendiri atau memecahkan suatu soal menjadi pertanyaan-pertanyaan yang lebih sederhana ${ }^{8}$. Sementara menurut Winingsih et al (2012:9) metode pembelajaran Problem Posing adalah sebuah metode yang memaksa peserta didik untuk lebih aktif dalam memecahkan masalah-masalah yang dijumpai, dengan belajar secara mandiri menggunakan cara mengajukan dan mengembangkan soal yang dibuat oleh peserta didik dan juga peserta didik mampu untuk menjawab soal tersebut ${ }^{9}$.

Dari pemaparan penjelasan di atas, maka akan dikembangkan suatu perangkat pembelajaran matematika berupa RPP dan LKPD yang bersesuaian dengan model pembelajaran Problem Posing untuk kelas VIII MTs Dar El Hikmah Pekanbaru. Sehingga judul dari penelitian adalah: "Pengembangan Perangkat Pembelajaran Matematika Problem Posing Berorientasi Kemampuan Pemecahan Masalah Matematis"

\section{METODE PENELITIAN}

Jenis penelitian yang digunakan adalah penelitian dan pengembangan (research and development) yang mempunyai tujuan untuk menghasilkan perangkat pembelajaran menggunakan model Problem posing berorientasi kemampuan pemecahan masalah matematis. Objek dalam penelitian ini ada perangkat pembelajaran berupa RPP dan LKPD yang waktu penelitiannya dilakukan pada semester genap tahun ajaran 2020/2021. Selanjutnya model pengembangan yang digunakan adalah model plomp yang mempunyai tiga fase yaitu yang pertama fase penelitian pendahuluan (preliminary research), kedua fase pembuatan prototype (prototyping phase), dan yang terakhir fase penilaian (assessment phase) ${ }^{10}$. Namun penelitian yang dilakukan pada fase penilaian (assessment phase) hanya dilakukan sampai tahap validasi perangkat pembelajaran saja, hal ini disebabkan oleh covid 19 yang menyebabkan tidak memungkinkan untuk melakukan uji coba pada lapangan.

Teknik pengumpulan data yang digunakan dalam penelitian pengembangan ini adalah validasi perangkat pembelajaran dengan Instrumen pengumpulan data yang digunakan yaitu lembar validasi yang digunakan untuk menguji kelayakan perangkat pembelajaran yang dikembangkan. Teknik analisis data dari pengembangan perangkat pembelajaran ini, menggunakan teknik analisis data statistik deskriptif. Berupa validasi perangkat pembelajaran yang akan diperoleh berdasarkan hasil analisis yang telah dilakukan oleh validator terhadap validasi yang diberikan. Dalam penelitiaan analisis ini menggunakan dua bentuk skala penilaian yaitu Skala Guttman dan Skala Likert untuk menentukan RPP dan LKPD valid atau tidak. Analisis data validasi untuk RPP dan LKPD dikatakan valid jika rata-rata hasil validasi menunjukkan hasil lebih dari $70 \%$. 
Pengembangan Perangkat Pembelajaran Menggunakan Model Problem Posing Berorientasi Kemampuan Pemecahan Masalah Matematis

Resyania Aprilla Putri ${ }^{1)}$, Endang Istikomah ${ }^{2)}$

\section{HASIL DAN PEMBAHASAN}

Hasil pengembangan perangkat pembelajaran matematika dengan menggunakan model Plomp terdiri dari tiga fase, yaitu sebagai berikut:

\section{a. Fase Pendahuluan (preliminary research)}

Pada fase ini terdapat beberapa analisis yang dilakukan, yaitu analisis masalah, analisis kurikulum, analisis peserta didik dan analisis materi. Pada keempat tahap tersebut peneliti melakukan wawancara dengan salah satu guru matematika yang mengajar hasil dari wawancara yang peneliti lakukan, peneliti menemukan informasi bahwa bahwa kurikulum yang digunakan dalam perangkat pembelajaran tersebut sudah menggunakan kurikulum 2013 namun pembelajaran yang dilakukan masih tidak sesuai dengan waktu yang telah dijabarkan dalam RPP ini disebabkan oleh RPP yang digunakan tidak dibuat sendiri oleh guru melainkan didapat dari buku paket yang dibeli oleh sekolah, dan dalam pebelajarannya tidak terlalu menggunakan LKPD, LKPD hanya digunakan untuk materi tertentu sehingga pembelajaran masih sering bersifat teacher centered, serta dalam pembelajaran matematika ini peserta didik masih sulit untuk memecahkan suatu masalah ketika diberi suatu soal, hal ini akan menjadi suatu penghambat bagi peserta didik untuk melanjutkan ke materi selanjutnya yang akan dipelajari. Salah satu materi yang sulit dipahami oleh peserta didik adalah materi statistika. Pada materi ini siswa cenderung sulit menemukan informasi yang terdapat dalam soal dan sulit menjadikannya kedalam model matematika.

\section{b. Fase Pembuatan Prototipe (Prototyping Phase)}

Pada tahap ini peneliti membuat prototype perangkat pembelajaran matematika sesuai dengan permasalah yang ada disekolah tersebut yaitu Rencana Pelaksanaan Pembelajaran (RPP) dan juga Lembar Kerja Peserta Didik (LKPD) dengan menggunakan model Problem Posing betorientasi kemampuan pemecahan masalah matematis siswa.

\section{c. Fase Penilaian (Assessment Phase)}

Pada tahap ini dilakukan validasi dan revisi perangkat pembelajaran agar memperoleh perangkat pembelajaran yang lebih baik. Perangkat pembelajaran yang peneliti kembangkan, divalidasi oleh tiga orang validator yaitu dua orang dosen FKIP Matematika UIR yaitu Ibu Zetriuslita dan Ibu Aulia Sthephani serta satu orang guru matematika di MTs Dar El Hikmah Pekanbaru yaitu Ibu Eli Marnis. Berikut merupakan hasil validasi dari RPP dan LKPD:

\section{1) Validasi pada RPP}

Untuk mengetahui kevalidan dari RPP didapatkan dengan cara mencari rata-rata dari setiap aspek. Berdasarkan perhitungan RPP setiap aspek diperoleh rata-rata sebagai berikut :

Tabel 1. Rata-Rata RPP pada Setiap Aspek

\begin{tabular}{|c|c|c|c|c|c|}
\hline \multirow{2}{*}{ Aspek yang Dinilai } & \multicolumn{3}{|c|}{ Persentase Validitas (\%) } & \multirow{2}{*}{$\begin{array}{l}\text { Rata- } \\
\text { Rata }\end{array}$} & \multirow{2}{*}{$\begin{array}{l}\text { Tingkat } \\
\text { Validasi }\end{array}$} \\
\hline & RPP-1 & RPP-2 & RPP-3 & & \\
\hline Kejelasan identitas RPP & $100 \%$ & $100 \%$ & $100 \%$ & $100 \%$ & Sangat valid \\
\hline $\begin{array}{l}\text { Perumusan indikator pencapaian } \\
\text { kompetensi dan tujuan } \\
\text { pembelajaran }\end{array}$ & $83,33 \%$ & $69,44 \%$ & $86,11 \%$ & $79,63 \%$ & Valid \\
\hline Materi yang disajikan & $77,08 \%$ & $68,75 \%$ & $75 \%$ & $73,61 \%$ & Valid \\
\hline
\end{tabular}


Jurnal Derivat, Volume 8 No.1 Juli 2021 (ISSN: 2549-2616)

Halaman $21-31$

\begin{tabular}{lccccc}
\hline Langkah-langkah pembelajaran & $70,83 \%$ & $75 \%$ & $75 \%$ & $73,61 \%$ & Valid \\
\hline Penilaian hasil belajar & $83,33 \%$ & $83,33 \%$ & $83,33 \%$ & $83,33 \%$ & Valid \\
\hline Bahasa & $100 \%$ & $91,67 \%$ & $91,67 \%$ & $94,44 \%$ & Sangat valid \\
\hline Waktu & $83,33 \%$ & $83,33 \%$ & $83,33 \%$ & $83,33 \%$ & Valid \\
\hline
\end{tabular}

Berdasarkan table 1. dapat disimpulkan bahwa pada aspek kejelasan indikator untuk RPP-1, RPP-2 dan RPP-3 mendapatkan skor rata-rata $100 \%$ untuk setiap pertemuan. Sehingga rata-rata dari aspek ini adalah $100 \%$ dengan kategori sangat valid. Hal ini menunjukkan bahwa adanya kekonsisten yang terjaga oleh peneliti dalam merumuskan setiap aspek indikator yang ada di dalam RPP. Pada aspek perumusan indikator pencapaian kompetensi dan tujuan pembelajaran, rata-rata skor untuk RPP-1 diperoleh 83,33\%; RPP-2 diperoleh 69,44\%; dan RPP-3 diperoleh 86,11\%. Sehingga rata-rata dari aspek ini adalah 79,63\% dengan kategori valid. RPP-2 memiliki nilai rata-rata skor paling rendah diantara ketiga RPP dikarenakan ada beberapa perumusan indikator dan tujuan pembelajaran yang kurang sesuai.

Pada aspek materi yang disajikan rata-rata skor untuk RPP-1 diperoleh 77,08\%; RPP-2 diperoleh 68,75\%; dan RPP-3 diperoleh 75\%. Sehingga rata-rata dari aspek ini adalah $73,61 \%$ dengan kategori valid. RPP-2 memiliki nilai skor paling rendah diantara ketiga RPP dikarenakan kurangnya kesesuaian materi dengan tujuan dan sistematika penyusunan RPP.

Pada aspek langkah-langkah pembelajaran disajikan rata-rata skor untuk RPP-1 diperoleh 70,83\%; RPP-2 diperoleh 75\%; dan RPP-3 diperoleh 75\%. Sehingga ratarata dari aspek ini adalah 73,61\% dengan kategori valid. RPP-1 memiliki nilai skor paling rendah diantara ketiga RPP dikarenakan ada beberapa langkah-langkah pembelajaran yang perlu diperjelas secara lebih rinci lagi.

Pada aspek penilaian hasil belajar dan aspek waktu indikator untuk RPP-1, RPP2 dan RPP-3 mendapatkan skor rata-rata 83,33\% untuk setiap pertemuan. Sehingga rata-rata dari aspek ini adalah 83,33\% dengan kategori valid. Hal ini menunjukkan bahwa adanya kekonsisten yang terjaga oleh peneliti dalam merumuskan setiap aspek indikator yang ada di dalam RPP. Kekurangan yang ada pada aspek ini disebabkan masih ada keraguan waktu yang dirancang dalam RPP cukup untuk guru dan peserta didik dalam mencapai tujuan pembelajaran setiap kali pertemuan di dalam kelas.

Pada aspek bahasa disajikan rata-rata skor untuk RPP-1 diperoleh 100\%; RPP-2 diperoleh 91,67\%; dan RPP-3 diperoleh 91,67\%. Sehingga rata-rata dari aspek ini adalah 94,44\% dengan kategori valid. RPP-2 dan RPP-3 memiliki nilai skor yang sama dikarenakan masih memiliki kekurangan adanya beberapa bahasa yang tidak sesuai dengan kaidah bahasa indonesia yang baik dan benar.

Selain itu peneliti juga menganalisis rata-rata hasil validasi dari setiap validator pada setiap per-pertemuan, yaitu sebagai berikut :

Tabel 2. Rata-Rata Validasi RPP Per-Pertemuan Setiap Validator Menggunakan Skala Guttman (Aspek indikator 1)

\begin{tabular}{cccccl}
\hline \multirow{2}{*}{ RPP } & \multicolumn{3}{c}{ Persentasi Validasi } & Rata-Rata & Tingkat Validasi \\
\cline { 2 - 4 } & $\mathbf{V}-\mathbf{\%}$ & $\mathbf{V - 2}$ & $\mathbf{V - 3}$ & \\
\hline RPP-1 & $100 \%$ & $100 \%$ & $100 \%$ & $100 \%$ & Sangat valid \\
\hline RPP-2 & $100 \%$ & $100 \%$ & $100 \%$ & $100 \%$ & Sangat valid \\
\hline RPP-3 & $100 \%$ & $100 \%$ & $100 \%$ & $100 \%$ & Sangat valid \\
\hline \multicolumn{7}{c}{ Rata-Rata Total } & & $100 \%$ & Sangat valid \\
\hline
\end{tabular}


Pengembangan Perangkat Pembelajaran Menggunakan Model Problem Posing Berorientasi Kemampuan Pemecahan Masalah Matematis

Resyania Aprilla Putri ${ }^{1)}$, Endang Istikomah ${ }^{2)}$

Tabel 3. Rata-Rata Validasi RPP Per-Pertemuan Setiap Validator Menggunakan Skala Likert (Aspek Indikator 2-7)

\begin{tabular}{|c|c|c|c|c|c|}
\hline \multirow{2}{*}{ RPP } & \multicolumn{3}{|c|}{ Persentasi Validasi } & \multirow{2}{*}{$\begin{array}{c}\text { Rata-Rata } \\
(\%)\end{array}$} & \multirow{2}{*}{$\begin{array}{c}\text { Tingkat } \\
\text { Validasi }\end{array}$} \\
\hline & V-1 & $\mathrm{V}-2$ & V-3 & & \\
\hline RPP-1 & $73,68 \%$ & $73,68 \%$ & $98,68 \%$ & $82,01 \%$ & Valid \\
\hline RPP-2 & $73,68 \%$ & $76,31 \%$ & $82,89 \%$ & $77,63 \%$ & Valid \\
\hline RPP-3 & $73,68 \%$ & $76,31 \%$ & $94,37 \%$ & $81,45 \%$ & Valid \\
\hline
\end{tabular}

Berdasarkan data hasil rata-rata validasi masing-masing validator, dapat dilihat RPP-1 sampai dengan RPP-3 tingkat validasi menggunakan skala Guttman dikategorikan sangat valid dan skala Likert dikategorikan valid. Hal ini menyebabkan RPP tersebut Layak digunakan namun harus dilakukan sedikit revisi sehingga RPP tersebut dapat digunakan. Semua saran dan masukan dari validator ahli melalui proses validasi telah disimpulkan sebagaimana terdapat pada tabel di atas.

2) Validasi pada LKPD

Untuk mengetahui kevalidan dari LKPD didapatkan dengan cara mencari ratarata dari setiap aspek. Berdasarkan perhitungan LKPD setiap aspek diperoleh rata-rata sebagai berikut :

Tabel 4. Rata-Rata RPP pada Setiap Aspek

\begin{tabular}{ccccccc}
\hline \multirow{2}{*}{ Aspek yang Dinilai } & \multicolumn{3}{c}{ Persentase Validitas (\%) } & \multirow{2}{*}{ Rata-Rata } & \multirow{2}{*}{ Kategori } \\
\cline { 2 - 5 } Isi yang Disajikan & LKPD-1 & LKPD-3 & LKPD-3 & & \\
\hline Aspek Materi & $75 \%$ & $93,33 \%$ & $93,33 \%$ & $93,33 \%$ & Sangat valid \\
\hline Aspek Bahasa & $75 \%$ & $75 \%$ & $75 \%$ & $75 \%$ & Valid \\
\hline
\end{tabular}

Berdasarkan dari data rata-rata hasil validasi LKPD untuk setiap aspek, aspek isi yang disajikan memiliki rata-rata tingkat validasi yang paling tinggi dibandingkan dengan aspek yang lain, yaitu 93,33\%. Kemudian untuk aspek materi dan aspek bahasa dengan nilai rata-rata validasi $75 \%$. Selain itu peneliti juga menganalisis rata-rata hasil validasi dari setiap validator, yaitu sebagai berikut :

Tabel 5. Rata-Rata Validasi LKPD Per-Pertemuan Setiap Validator Menggunakan Skala Guttman (Aspek Indikator 1)

\begin{tabular}{cccccc}
\hline \multirow{2}{*}{ RPP } & \multicolumn{6}{c}{ Menggunakan Skala Guttman (Aspek Indikator 1) } \\
\cline { 2 - 4 } & $\mathbf{V - 1}$ & $\mathbf{V - 2}$ & $\mathbf{V - 3}$ & Rata-Rata $(\%)$ & $\begin{array}{c}\text { Tingkat } \\
\text { Validasi }\end{array}$ \\
\hline LKPD-1 & $80 \%$ & $100 \%$ & $100 \%$ & $93,33 \%$ & Sangat valid \\
\hline LKPD-2 & $80 \%$ & $100 \%$ & $100 \%$ & $93,33 \%$ & Sangat valid \\
\hline LKPD-3 & $80 \%$ & $100 \%$ & $100 \%$ & $93,33 \%$ & Sangat valid \\
\hline \multicolumn{7}{c}{ Rata-Rata Total } & & $93,33 \%$ & Sangat valid \\
\hline
\end{tabular}

Tabel 6. Rata-Rata Validasi LKPD Per-Pertemuan Setiap Validator Menggunakan Skala Likert (Aspek Indikator 2-3)

\begin{tabular}{|c|c|c|c|c|c|}
\hline \multirow{2}{*}{ RPP } & \multicolumn{3}{|c|}{ Persentasi Validasi } & \multirow{2}{*}{ Rata-Rata (\%) } & \multirow{2}{*}{$\begin{array}{l}\text { Tingkat } \\
\text { Validasi }\end{array}$} \\
\hline & V-1 & V-2 & V-3 & & \\
\hline LKPD-1 & $75 \%$ & $75 \%$ & $75 \%$ & $75 \%$ & Valid \\
\hline LKPD-2 & $75 \%$ & $75 \%$ & $75 \%$ & $75 \%$ & Valid \\
\hline LKPD-3 & $75 \%$ & $75 \%$ & $75 \%$ & $75 \%$ & Valid \\
\hline \multicolumn{4}{|c|}{ Rata-Rata Total } & $75 \%$ & Valid \\
\hline
\end{tabular}


Berdasarkan dari hasil data rata-rata setiap validator yang dilakukan oleh 3 orang validator dapat dilihat bahwa LKPD-1 sampai dengan LKPD-3 tingkat validitasnya menggunakan skala Guttman dikategorikan sangat valid dan untuk penilaian skala Likert dikategorikan valid. Hal ini menyebabkan perlunya sedikit revisi pada Lembar Kerja Peserta Didik (LKPD) untuk dapat dikategorikan layak digunakan. Berikut hasil perbandingan RPP dan LKPD sebelum revisi dan juga sesudah revisi :

Tabel 7. Perbandingan RPP Sebelum dan Sesudah Revisi

\begin{tabular}{|c|c|c|c|c|c|c|}
\hline $\begin{array}{c}\text { Saran } \\
\text { validator }\end{array}$ & \multicolumn{3}{|c|}{ RPP Prototype-I } & \multicolumn{3}{|c|}{ Perbaikan RPP prototype-II } \\
\hline \multicolumn{7}{|l|}{ Validator-I } \\
\hline \multirow{2}{*}{$\begin{array}{l}\text { Tahapan } \\
\text { problem posing } \\
\text { dijelaskan di } \\
\text { RPP. }\end{array}$} & KEGIATAN & \multicolumn{2}{|c|}{ LANGKAH-LANGKAH PEMBELAJARAN } & \multirow{2}{*}{\begin{tabular}{|l|} 
KEGLATAN \\
Pendahuluan \\
\end{tabular}} & \multicolumn{2}{|c|}{\begin{tabular}{|l} 
LANGKAH-LANGKAHPEMBELAJARAN \\
\end{tabular}} \\
\hline & 'endahuluan & \multicolumn{2}{|c|}{$\begin{array}{l}\text { (Tahap I Problem Posing) } \\
\text { - Guru membuka pelajaran dengan mengucapkan } \\
\text { salam dan mengarahkan peserta didik untuk } \\
\text { berdoa sesuai kepercayaanya masing-masing. } \\
\text { - Guru mengecek kehadiran peserta didik serta } \\
\text { menanyakan kabar dan kesiapan peserta didik } \\
\text { untuk belajar. } \\
\text { - Guru memberitahu peserta didik tentang } \\
\text { pendekatan pembelajaran yang akan digunakan } \\
\text { yaitu dengan menggunakan model } \\
\text { pembelajaran Problem Posing dan tujuan } \\
\text { pembelajaran yang harus di capai pada } \\
\text { pertemuan kali ini. }\end{array}$} & & \multicolumn{2}{|c|}{$\begin{array}{l}\text { a. Guru memasuki ruangan kelas dengan } \\
\text { mengucapkan salam. } \\
\text { b. Guru meminta salah satu peserta didik } \\
\text { untuk memipin doa sebelum belajar. } \\
\text { c. Guru mengesek kehadiran peserta didik " } \\
\text { hari ini siapa teman kalian yang tidak } \\
\text { hadir?" } \\
\text { d. Guru menginformasikan materi yang akan } \\
\text { dipelajari pada hari ini yaitu mengenai } \\
\text { statistika. } \\
\text { Langkah } 1 \text { PP: Guu menvampaikan tujuan } \\
\text { pembelajaran }\end{array}$} \\
\hline \multirow{2}{*}{$\begin{array}{l}\text { Penataan letak } \\
\text { RPP } \\
\text { diperbaiki. }\end{array}$} & KEGIATAN I & LANGKAH-LANGKAH PEMBELAJARAN & $\begin{array}{c}\text { Alokasi } \\
\text { Waktu }\end{array}$ & \begin{tabular}{|l|l|} 
KEGLATAN & L \\
\end{tabular} & LANGKAH-LANGKAH PENBELAJARAN & Alokasi Waktu \\
\hline & . & 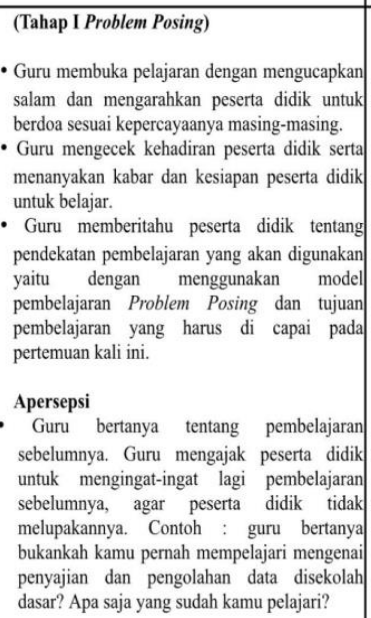 & 10 menit & Pendahuluan & 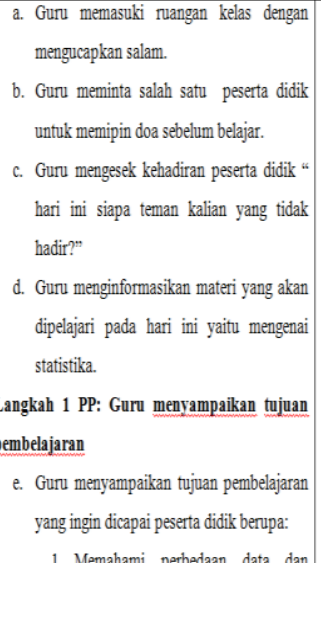 & $R_{G}^{A}$ \\
\hline
\end{tabular}




\begin{tabular}{|c|c|c|}
\hline $\begin{array}{l}\text { Pendekatan } \\
\text { saintifik pada } \\
\text { RPP belum } \\
\text { diletakkan } \\
\text { pada porsi } \\
\text { yang benar. }\end{array}$ & \begin{tabular}{|l} 
(Tahap IV Problem Posing) \\
Mengamati \\
- Guru meminta peserta didik mengamati cara \\
penyajian data dalam bentuk tabel dan diagram \\
batang. \\
- Guru meminta peserta didik mengamati contoh \\
soal tentang penyajiandata dalam bentuk tabel \\
dan diagram batang. \\
- Guru meminta tiap kelompok membuat soal \\
berdasarkan informasi yang diberikan pada \\
LKPD serta setiap anggota kelompok harus \\
mampu menyelesaikan soal yang telah dibuat \\
oleh kelompoknya sendiri.
\end{tabular} & \begin{tabular}{|l|} 
Mengamati \\
Langkah 4 PP: guru menjelaskan materi \\
pelajaran kepada peserta didik. \\
a. Guru menyampaikan materi pelajaran \\
secara garis besar dimana guru hanya \\
menyajikan sub-sub judul materi, untuk \\
pertemuan ini sub materinya "data" \\
Menanya \\
b. Guru memberikan kesempatan untuk \\
menanyakan hal yangbelum dipahami oleh \\
peserta didik. \\
Langkah 5 PP: guru membagi LKPD dan LPP \\
kenada masing-masing kelomnok.
\end{tabular} \\
\hline $\begin{array}{l}\text { Kemampuan } \\
\text { pemecahan } \\
\text { masalah tidak } \\
\text { terjawab di } \\
\text { RPP. }\end{array}$ & $\begin{array}{l}\text { (Tahap IV Problem Posing) } \\
\text { Mengamati } \\
\text { - Guru meminta peserta didik mengamati cara } \\
\text { penyajian data dalam bentuk tabel dan diagram } \\
\text { batang. } \\
\text { - Guru meminta peserta didik mengamati contoh } \\
\text { soal tentang penyajiandata dalam bentuk tabel } \\
\text { dan diagram batang. } \\
\text { - Guru meminta tiap kelompok membuat soal } \\
\text { berdasarkan informasi yang diberikan pada } \\
\text { LKPD serta setiap anggota kelompok harus } \\
\text { mampu menyelesaikan soal yang telah dibuat } \\
\text { oleh kelompoknya sendiri. } \\
\text { - Guru membimbing dan membantu kelompok } \\
\text { yang mengalami kesulitan dalam pembuatan } \\
\text { soal. } \\
\text { Guru meminta tiap kelompok untuk saling } \\
\text { menukarkan lembar pengajuan soal kepada } \\
\text { kelompok lain } \\
\text { Guru meminta tiap kelompok untuk } \\
\text { menyelesaikan soal yang ada ada lembar } \\
\text { pengajuan soal dari kelompok lain secara } \\
\text { berkelompok yang ditulis pada lembar } \\
\text { penyelesaian soal. }\end{array}$ & \begin{tabular}{|} 
Mengeksplorasikan \\
d. Guru meminta peserta didik untuk \\
menyelesaikan permasalahan yang ada \\
pada LKPD dengan teman sekelompoknya. \\
Langkah 6 PP: guru meminta peserta didik \\
memahami dan menjawab soal yang ada pada \\
LKPD yang akan menjadi acuan untuk \\
membuat pertanyaan di lembar LPP. \\
e. Guru meminta peserta didik memahami \\
dan menjawab soal yang ada pada lemabar \\
LKPD yang akan menjadi acuan untuk \\
membuat pertanyaan di lembar LPP. \\
Langkah 7 PP: guru memberikan contoh cara
\end{tabular} \\
\hline
\end{tabular}


Tabel 8. Perbandingan LKPD Sebelum dan Sesudah Revisi

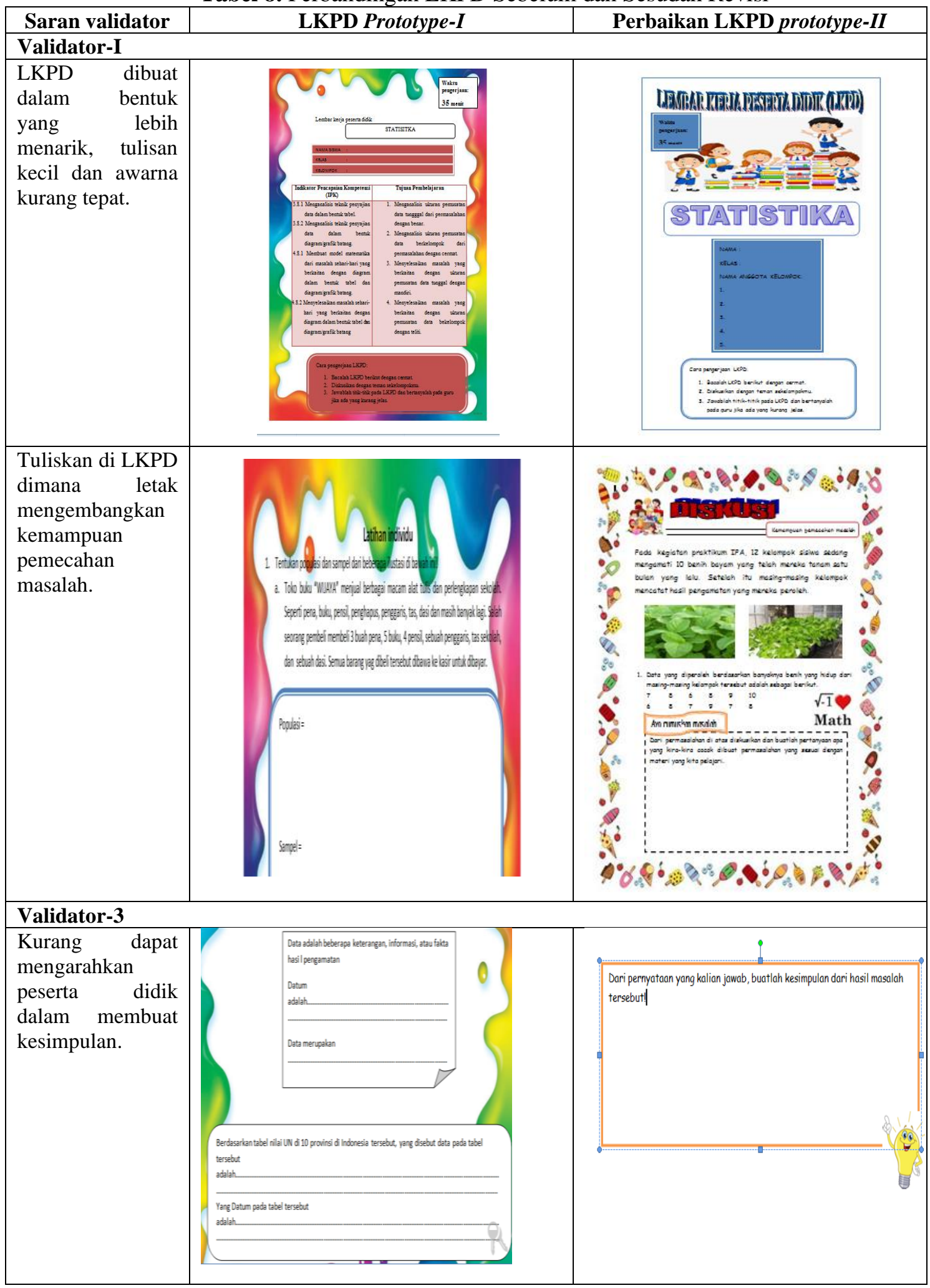


Pengembangan Perangkat Pembelajaran Menggunakan Model Problem Posing Berorientasi Kemampuan Pemecahan Masalah Matematis

Resyania Aprilla Putri ${ }^{1)}$, Endang Istikomah ${ }^{2)}$

Adapun tahap keseluruhan daran pengembangan perangkat pembelaran dengan menggunakan model Problem Posing berorientasi kemampuan pemecahan masalah matematis mencakup tiga langkah penting yaitu 1) Fase Pendahuluan, 3) Fase pembuatan Prototype, dan 3) Fase Penilaian. Pada fase penilian hanya sampai tahap validasi saja, hal ini di sebabkan oleh covid 19 yang tidak memungkinkan untuk melakukan tahap uji coba. Berdasarkan prosedur yang peneliti lakukan, hasil validasi RPP untuk setiap aspek pada RPP-1 terdapat nilai tertinggi yaitu $100 \%$ dimana nilai tersebut berasal dari aspek kejelasan identitas RPP. Sedangkan untuk aspek yang terendah dengan nilai persentase 70,83\% yaitu pada aspek langkah-langkah pembelajaran, hal ini disebabkan karena ada beberapa langkah-langkah pembelajaran dan tujuan pembelajaran yang kurang jelas dan perlu dijelaskan secara lebih rinci lagi. Hasil validasi RPP untuk setiap aspek pada RPP-2 dan RPP-3 terdapat nilai tertinggi yaitu 100\% dimana nilai tersebut berasal dari aspek kejelasan identitas RPP. Sedangkan untuk aspek yang terendah untuk RPP-2 dan RPP-3 dengan nilai persentase masing-masing yaitu 68,75\% dan $73,61 \%$ aspek materi yang disajikan hal ini disebabkan oleh kurangnya sumber belajar dan kurangnya kesesuaian antara materi dengan tujuan dan sistematika penyusunan RPP.. Kemudian diperoreh nilai rata-rata validasi setiap validator pada per-pertemuan dari Rencana Pelaksanaan Pembelajaran (RPP) yang memiliki tingkat validasi sangat valid dengan rata-rata $100 \%$ untuk pengukuran menggunakan skala guttman. Serta memiliki tingkat validasi valid dengan rata-rata $80,36 \%$ pengukuran dengan skala likert pada aspek indikator dua sampai tujuh. Sedangkan rata-rata validasi setiap validator pada per-pertemuan dari Lembar Kerja Peserta Didik (LKPD) yang memiliki tingkat validasi sangat valid dengan rata-rata 93,33\% untuk pengukuran menggunakan skala guttman. Serta memiliki tingkat validasi valid dengan rata-rata $75 \%$. dengan pengukuran dengan skala likert pada aspek indikator dua sampai tiga. Dari data kevalidan dari RPP dan LKPD tersebut mengisyaratkan bahwa perangkat pembelajaran yang peneliti lakukan termasuk efektif dan bisa atau dapat digunakan tetapi dengan melakukan sedikit revisi.

\section{KESIMPULAN}

Berdasarkan hasil penelitian dan pembahasan yang telah dijabarkan dapat disimpulakan bahwa pengembangan perangkat pembelajaran menggunakan medel Problem Posing berorientasi kemampuan pemecahan masalah matematis pada materi statistika menghasilkan produk Rencana Perancanaan Pembelajaran (RPP) dan Lembar Kerja Peserta Didik (LKPD) yang valid. Sehingga perangkat pemebelajaran yang diperoleh termasuk efektif dan bisa atau dapat digunakan tetapi dengan melakukan sedikit revisi.

\section{RFERENSI}

Hamdani. 2011. Strategi Belajar Mengajar. Bandung: Pustaka Setia.

Jamal, F. 2018. Analisis Kesalahan Dalam Menyelesaikan Soal Cerita Pertidaksamaan Kuadrat Berdasarkan Prosedur Newman. Maju (Jurnal Ilmiah Pendidikan Matematika), 5(2), 41-51.

Pertiwi, E., \& Istikomah, E. 2020. Kooperatif Tipe Team Assisted Individualization pada Materi Relasi dan Fungsi : Suatu Model Pembelajaran untuk Meningkatkan Hasil Belajar Matematika Siswa. Jurnal Aksiomatik, 8(1), 51-58.

Plomp T. Educational Design Research: An Introduction (Plomp, $T$ \& Nieveen, Ed.). Netherlands Institute for Curriculum Development (SLO). 2013. 
Jurnal Derivat, Volume 8 No.1 Juli 2021 (ISSN: 2549-2616)

Halaman $21-31$

Shoimin, Aris. 2014. 68 Model Pembelajaran Inovatif Dalam Kurikulum 2013. Yogyakarta: Ar- Ruzz Media.

Trianto. 2012. Model Pembelajaran Terpadu Konsep, Strategi, dan Implementasinya dalam Kurikulum Tingkat Satuan Pendidikan (KTSP). Bumi Aksara.

Widjajanti, E. 2008. Pelatihan Penyusunan LKS Mata Pelajaran Kimia Berdasarkan Kurikulum Tingkat Satuan Pendidikan Bagi Guru SMK/MAK.

Winingsih, Yulia, Erliany Syaodih, and Popon Mariam. 2012. "Pengembangan Metode Pembelajaran Problem Posing Untuk Meningkatkan Kemampuan Berpikir Analisis." EDUCARE 10(2):7-13.

Yolanda, F., \& Wahyuni, P. 2020. Pengembangan Bahan Ajar Berbantuan Macromedia Flash. SJME (Supremum Journal of Mathematics Education), 4(2), 170-177.

Zetriuslita, \& Wirmaningsih, D. A. 2013. Meningkatkan Hasil Belajar Matematika Melalui Penerapan Model Pembelajaran Problem Posing. Jurnal Mthematics Pedagogic, 3(2). 